\title{
Alfred Sohn-Rethel:
}

\section{Kapitalismens sociale rekonsolidering}

\section{(September 1932)}

Gennem en analyse af den tyske Weimar-republik viser Sohn-Rethel her, at Socialdemokratiets historiske rolle har været at rekonsolidere det kapitalistiske samfund. Sohn-Rethel fortsætter den teori, hvis objektive virkelighed på blodig vis ramte Liebknecht, Luxemburg og hele den tyske arbejderbevægelse.

Ebert, Friedrich, socialdemokrat; den første præsident for den tyske republik (1919-1925).

keynesianisme, efter den britiske økonom John Maynard Keynes, 1883-1946, som efter 1929 støttede både omfattende økonomisk planlægning på regeringsplan og offentlige udgifter for at holde beskæftigelsen i vejret. (Heraf den almindelige forvirring da præsident $\mathrm{Ni}$ xon dette forår erklærede at være keynesianer, stik modsat det republikanske partis hidtidige politik).

$K P D=$ Kommunistische Partei Deutschlands, Tysklands kommunistiske parti.

$N S D A P=$ Nationalsozialistische Deutsche Arbeiterpartei, det tyske nationalsocialistiske (= nazistiske) parti.

Reichswehr (rigsværn), den hvervede hær på 100.000 mand, som Tyskland iflg. Versaillestraktaten måtte have.

Schacht, H. H. G:, tysk bankier og økonom; præsident for Reichsbank (rigsbanken) 192330 m.m.; stabiliserede den inflationsramte kurs (1924-25; hjalp senere som økonomiminister (1934-37) til genoprustningen under Hitler uden dog at være nazist.

taylorismen, efter Frederick Taylor (f. 1856), faderen til moderne managementteori; han søgte at udvikle teknikker til størst mulig effektivisering af arbejderes præstationer; den ideelle arbejder var for ham kort sagt en effektiv maskine.

Papen, Franz von (f. 1879), tysk politiker; 1921-31 medlem af rigsdagen (Zentrum), juninov. 1932 rigskansler, banede som sådan vej for Hitler.

Weimar-koalitionen, koalitionen under Weimar-republikken, uofficiel betegnelse for Tyskland under den i Weimar vedtagne forfatning af 1919; præsidenter var Ebert (1919-25) og Hindenburg (1925-34). 
Den opgave, som det i de sidste par måneder har drejet sig om at løse og som det også vil dreje sig om, efter at den nuværende tilspidsede situation er overstået, er rekonsolideringen af det borgerlige regime i Tyskland. Den nuværende regering von Papen betyder endnu ikke denne rekonsolidering, skønt den selv påstår det, og skønt denne påstand er en taktisk rigtig og nødvendig fiktion for at opretholde en fuldgyldig regeringsduelighed. Hvis denne regering virkelig bragte og betød den påkrævede rekonsolidering, så måtte den, i stedet for at udskrive nyvalg, være tilstrækkeligt mægtig til helt at suspendere Rigsdagen og behøvede ikke at måtte frygte, at den ved et sådant kup fik buen til at briste. Følgelig er regeringen afhængig af endnu ubundne kræfter, kræfter der endnu ikke er inddraget i den, og rekonsolideringen forestår altså endnu i Tyskland.

Det er imidlertid ikke den første, som er blevet gennemført i efterkrigstidens Tyskland. Der er slet ingen tvivl om, at efter revolutions- og inflationsårenes stormløb havde sat spørgsmålstegn ved alt, betød Weimarkoalitionen med den succesrige gennemførelse af det »store økonomiske program«, stabiliseringen 1923/24, og målt med den ophobning af kræfter, der dengang måtte tøjles, i enhver henseende en rekonsolidering af det borgerlige regime. Den har politisk varet til det ny kriseudbrud i 1930. Dette viste ganske vist, at den som rekonsolidering kun var tilsyneladende og mangelfuld, og bevirkede i sit videre forløb dens opløsning og sprængning, ligesom allerede udbruddet af krisen 1918/19 havde nedbrudt og opløst krigstidens kejserlige system. Den tyske efterkrigstids historie indeholder altså forløb, der er dynamisk beslagtede med den nuværende problemstilling, og hvoraf man ved en opmærksom sammenligning kan drage slutninger til brug for de nuværende opgaver. Parallellen går i virkeligheden forbløffende vidt. Det daværende Socialdemokrati og den nuværende nationalsocialisme ligner funktionelt hinanden deri, at de begge bar det forudgående system til graven og lænkede de af dem førte masser til en ny udformning af det borgerlige herredømme i stedet for til den proklamerede revolution. Den ofte foretagne sammenligning mellem Ebert og Hitler har i denne henseende sin gyldighed. Der består det yderligere strukturelle slægtskab mellem de strømninger, der kaldte dem til live, at de begge var folkebevægelser - kun har man glemt det om det socialdemokratiske højvande 1918/19 - at begge med appellen til antikapitalistiske befrielseslængsler lovede virkeliggørelsen af et nyt - »socialt « eller »nationalt « - folkefællesskab, desuden at deres tilhængeres sociale sammensætning er fuldstændigt sammenfaldende i småborgerskabets masser, ja endog langt udenfor det, og endeligt at deres åndelige karakter udmærker sig ved en helt igennem beslægtet forvirring og en ligeså sværmerisk-troende som kortfristet troskab. Konstateringen af denne parallel er ingen nedvurdering af den nationalsocialistiske idé, den rammer overhovedet ikke ideer, men gælder den rent analytiske erkendelse af de to massebevægelsers funktion og betydning, der, i to homologe historiske øjeblikke, har spillet, henholdsvis stadig spiller, en analog politisk rolle i samme sociale rum. Selve parallellen betyder, at nationalsocialismen må afløse Socialdemokratiet i den opgave at frembyde massestottepunktet for borgerskabets herredømme i Tyskland. Dette indeholder samtidig, for sin del, den nøjere problemstilling for den nuværende påbudte rekonsolidering af dette herredømme. Er nationalsocialismen i stand til at overtage denne støttefunktion i stedet for Socialdemokratiet, og på hvilken måde kan det foregå?

Problemet om rekonsolideringen af det borgerlige regime i efterkrigstidens Tyskland er alment bestemt ved den kendsgerning, at det førende borgerskab, nemlig det der råder over økonomien, er blevet for snavert til at bære sit herredømme alene. Hvis det ikke vil betro sig til den rent militære magtudøvelse, der er et højst farligt våben, kræves der til dette herredømme tilslutning fra lag, der socialt ikke tilhører det, men som yder det den uvurderlige tjeneste at forankre dets herredømme i folket og derved være dets egentlige eller virkelige bærer. Denne virkelige bærer eller »grænsebærer « af det borgerlige herredømme var i den første periode af efterkrigstidens konsolidering Socialdemokratiet.

Til denne opgave medbragte det en egenskab, som nationalsocialismen mangler, i det mindste endnu mangler. Vel var også novembersocialismen en ideologisk strømning hos masserne og en bevægelse, men den var ikke kun det, for bag den stod arbejdernes organiserede magt, fagforeningernes sociale magt. Stormfloden kunne synke, det ideologiske stormløb bryde sammen, bevægelsen ebbe ud, men fagforeningerne blev og med dem, eller rettere, i kraft af dem, det Socialdemokratiske Parti. Nationalsocialismen er derimod frem for alt kun bevægelsen, det blotte stormløb, fremrykningen og ideologien. Bryder denne væg sammen, så støder man bag 
den ud i tomheden. For idet den omfatter alle lag og grupper, er den ikke identisk med nogen af dem, er den ikke sociologisk legemliggjort i noget varende led i samfundsbygningen. I denne vigtige omstændighed ligger, ved siden af den ovenfor fastslåede parallel mellem de to massebevægelser, den fundamentale forskel med hensyn til deres betydning for rekonsolideringen af det borgerlige herredømme. På grund af sin sociale karakter som oprindeligt arbejderparti bragte Socialdemokratiet bortset fra al sin politiske slagkraft, det der var et langt mere værdifuldt og varende gode, nemlig den organiserede arbejderbevægelse ind i det daværende konsolideringssystem og kædede den solidt sammen med den borgerlige stat under paralysering af dens revolutionære energi. På denne basis kunne Socialdemokratiet stille sig tilfreds med den blotte deltagelse i det borgerlige herredømme, ja kunne det endog aldrig være mere og efter sit væsen intet andet end blot den ene parthaver i dette. Det var hørt op med at være socialdemokrati, hvis tiltilfældet havde skænket det hele magten over staten, økonomien og samfundet, i den grad at man med et kendt udtryk kunne sige om det: hvis det borgerlige samfund ikke eksisterede, var Socialdemokratiet blevet nødt til at opfinde det for at kunne bestå.

I modsætning hertil betinger manglen på social magt Nationalsocialismens fascistiske karakter. Da den ikke har noget specifikt socialt grundlag, der kunne bære nationalsocialismen også uden Hitler, kan den kun enten erobre den samlede magt for gennem besiddelsen af statsapparatet at skaffe sig, hvad den mangler i socialt grundlag, eller dens kraft bryder sammen overfor den sociale struktur, som modstår den og som den ikke kan komme ind i. Fordi den ikke primært er noget led i denne struktur, kan den ikke uden en grundlæggende forvandling være en parthaver i det borgerlige herredømme, der bygger på samfundsmæssig mågt, og kun kræver politisk støtte og forankring, "massebasis«, i bunden af den sociale leddeling. Her er den nuværende situations sande prøvesten. Nationalsocialismens fascistiske mulighed er forbi, dens sociale mulighed endnu ikke fundet. Om vi nu virkelig når frem til en ny og produktiv rekonsolidering, eller om vi står i den blindgyde som alternativet: militærdiktatur eller tilbagevenden til Socialdemokratiet, er, afhænger af om den bliver fundet. Det hele kan derfor sammenfattes i spørgsmålet, om der er en specifik social mulighed for nationalsocialismen, hvorved den kan forvandles fra at være en fascistisk bevægelse til at blive en parthaver i det borgerlige herredømme, således at den for borgerskabet kan erstatte Socialdemokratiet i dets hidtidige rolle. Næste artikel skal tjene til belysning af dette problem.

\section{Indlemmelsen af nationalsocialismen.}

I en tid hvor rekonsolideringen af det borgerlige herredømme er et spørgsmål om liv og død, kan man om nødvendigt blive tvunget til med magt at sætte en stopper for den naionalsocialistiske bevægeses fascisme, men kun for samtidigt at forvandle Nationalsocialismen til et samfundsmassigt organ, som kan tjene som støtte for dette herredømme og positivt kan indlemmes i dettes statslige udformning. De muligheder, der frembyder sig til dette formål, kan her kun antydes i al korthed. Den nødvendige betingelse for enhver social rekonsolidering af det borgerlige herredømme, som er mulig i Tyskland efter krigen, er arbejderbevagelsens spaltning. Enhver lukket arbejderbevægelse, der voksede op nedefra, måtte være revolutionær og mod en sådan ville dette herredømme ikke være i stand til at klare sig i længden, heller ikke ved hjælp af militær magtanvendelse. På den fælles basis, der udgøres af denne nødvendige betingelse, adskiller de forskellige systemer af borgerlig konsolidering sig ved de tilstrakkelige betingelser, der må føjes til for at forankre staten og borgerskabet $\mathrm{i}$ brede lag af den spaltede arbejderbevægelse.

I det borgerlige efterkrigsregimes første rekonsolideringsæra, tiden fra 1923/24 til 1929/30, lå grunden til spaltningen af arbejderbevægelsen i de lon- og socialpolitiske resultater, som Socialdemokratiet havde udmøntet den revolutionære stormflod i. Disse fungerede nemlig som en slags slusemekanisme, gennem hvilken den beskæftigede og fast organiserede del af arbejderne på arbejdsmarkedsplanet nød en - ganske vist trindelt, men alligevel i sig selv betydelig - niveaufordel overfor den arbejdsløse og fluktuerende masse i de laveste kategorier, relativt beskyttet mod den fulde virkning af arbejdsløsheden og den almindelige krisesituation inden for økonomien. Den politiske grænse mellem socialdemokrati og kommunisme løber næsten nøjagtig langs dette slusediges sociale og økonomiske linie, og kommunismens samlede anstrengelser, der indtil nu dog har været forgæves, gælder fremstødet mod fagforeningernes beskyttede område. Da den socialdemokratiske udmøntning af revolutionen i socialpolitik faldt sammen med kampens forlægning fra fabrikkerne og gaden til parlamentet, 
ministerierne og kontorerne, d.v.s. med forvandlingen af kampen »fra neden « til sikringen »fra oven«, var Socialdemokratiet og fagforeningsbureaukratiet, og med dem den del af arbejderne, der fulgte deres ledelse, med hud og hår bundet til den borgerlige stat og deres meddelagtighed i magten kædet sammen med den. Dette gælder i hvert fald så længe, der, for det første, er blot det mindste tilbage at forsvare på denne måde og, for det andet, så længe arbejderne vil følge deres ledelse.

Man kan drage fire vigtige slutninger af denne analyse: 1 . Det "mindste ondes« politik, er ikke en taktik, den er Socialdemokratiets politiske substans. 2. Fagforeningsbureaukratiets tilknytning til den statslige vej "fra oven « er mere tvingende end dets tilknytning til marxismen, altså til Socialdemokratiet og gælder overfor enhver borgerlig stat, der vil inddrage det. 3. Fagforeningsbureaukratiets tilknytning til Socialdemokratiet står og falder politisk med parlamentarismen. 4. Muligheden for en liberal socialforfatning i monopolkapitalismen er betinget af tilstedeværelsen af en automatisk spaltningsmekanisme blandt arbejderne. Et borgerligt regime, som finder en liberal socialforfatning magtpåliggende, må støtte sig til Socialdemokratiet og overlade det tilstrækkelige resultater; et borgerligt regime, som tilintetgør disse resultater, må ofre Socialdemokratiet $o g$ parlamentarismen, må skaffe sig en erstatning for Socialdemokratiet og overgå til en bunden socialforvaltning.

Den overgangsproces, som vi for øjeblikket befinder os i, da den økonomiske krise naturnødvendigt har knust disse resultater, gennemløber det akutte farestadium, hvor den på disse resultater beroende spaltningsmekanisme hos arbejderne er hørt op med at virke, hvorved arbejderne er ved at bevæge sig i retning af kommunismen, og det borgerlige herredømme nærmer sig grænsen til militcrdiktaturets undtagelsestilstand. Men at træde ind i denne undtagelsestilstand ville være at træde ind $i$ et uhelbredeligt borgerligt herredømme, fra en fase med nødlidende konslidering. Det er kun muligt at undgå at falde i denne afgrund, hvis arbejderbevægelsens spaltning og tilknytning lykkes på en anden og mere direkte måde, da slusemekanismen ikke i tilstrækkelig grad kan genoprettes. Her ligger nationalsocialismens positive muligheder og opgaver. Problemet selv anviser den to retninger. Enten indlemmer man den del af arbejderne, der er beskæftiget i den frie del af erhvervslivet, d.v.s. fagforeningerne, i en standerforfatning ved hjælp af en ny form for politisk sammenkædning, eller man forsøger omvendt at støtte sig til den arbejdsløse del idet man organiserer en kunstig sektor inden for økonomien med arbejdstvang.

Ved fagforeningernes frigørelse fra Socialdemokratiet mister de deres hidtidige politiske repræsentation, i hvis sted de - i en stat der ikke, eller i hvert fald kun meget betinget, er parlamentarisk - har brug for en ny og hidtil uset form for politisk ledelse. Hvis det lykkedes nationalsocialismen at overtage denne ledelse og bringe fagforeningerne ind i en bunden socialforfatning, ligesom Socialdemokratiet tidligere har bragt dem ind i en liberal, ville nationalsocialismen derved blive bærer af en for det fremtidige borgerlige herredømme uundværlig funktion og måtte nødvendigvis finde sin organisatoriske plads i dette herredømmes social- og statssystem. Faren for en statskapitalistisk eller endog socialistisk udvikling der ofte fremføres mod en sådan indordning af fagforeningerne under nationalsocialistisk ledelse efter stænderprincippet, bliver i virkeligheden netop forhindret på denne måde. Den »tredje front«, som Tatkreis propaganderer for, er prototypen på en falsk konstruktion, som de dukker op i tider med socialt vakuum; den er et fantasifoster fra en overgangstilstand, i hvilken fagforeningerne, der er løst fra deres hidtidige bånd og endnu ikke indfanget i nogle nye, giver udseende af at have en egeneksistens, som de ifølge deres natur slet ikke kan være i besiddelse af. Der er ingen tredje vej mellem de to muligheder: en rekonsolidering af det borgerlige herredømme eller den kommunistiske revolution.

Der er ganske vist, i det mindste teoretisk, en anden vej ved siden af indordningen af fagforeningerne efter stænderprincippet til støtte for det borgerlige herredømme, nemlig den at organisere og binde den arbejdsløse befolkning til staten ved hjælp af arbejdstvang og kolonisation. Denne opgave synes at ligge nationalsocialismens inderste væsen, der ikke er vokset organisk frem, særligt nær, og her har man da også gennemtænkt den grundigst. Men man må være klar over, at de to nævnte veje involverer meget forskellige udviklingslinjer for den samlede økonomi. En nævneværdig indordning af de arbejdsløse masser i det sociale folkefællesskab ved hjælp af arbejdstvang er kun mulig gennem vidtrækkende stats- og planøkonomiske metoder, som af økonomiske såvel som af finansielle grunde må svakke den fri økonomiske sektor. Da man kun kan betræde denne vej 
ved at overbebyrde den frit beskæftigede del af arbejderne, måtte et sådant regime uundgåeligt forlægge den sociale hovedvægt til landbrugssektoren, ville altså ved en ekstrem autárkipolitisk berøve eksportindustrien og de interesser, der er knyttet til den, enhver chance, umuliggøre en tilknytning til forbedrede verdenskonjunkturer, følgelig forøge den arbejdsløse del af befolkningen og endelig lægge en stor del af den samlede økonomi fast i en statslig fattigdomsøkonomis tvangssystem. Om man kan betegne dette som en rekonsolidering, må synes tvivlsomt. Denne vej kan derfor kun partielt og i ren subsidiar betydning, som den er benyttet i regeringens økonomiske program, lette overgangen til et system med virkelig rekonsolidering af det borgerlige herredømme, der som før må støtte sig på den faste kerne hos arbejderne, fagforeningerne under ny ledelse.

\section{Alfred Sohn-Rethel. \\ En kommentar 38 år efter.}

Den artikel fra Deutsche Führerbriefe, der her er blevet genoptrykt, udløste en enestående sensation, da den fremkom (16. og 20. september 1932). Siden da har man stadig citeret den og henvist til den, og til i dag har karakteren af en uløst gåde klæbet til den. Grunden hertil ligger ikke i indholdet. Marxistiske analyser af de daværende klasseforhold og magtforskydninger i Tyskland var på dagsordenen, uden at nogen bestemt version havde kunnet vinde klar forrang frem for de andre. Det sensationelle ved denne specielle analyse lå i dens fremkomststed og i den kendsgerning, at den var foretaget ud fra klassefjendens, storkapitalens, standpunkt. Var det en frafalden marxist, der var ifærd med at tiltræde rollen som tysk Mussolini? Sådan forekom det næsten medlemmerne af KPD's partiledelse. Det manglede lige, at der fremstod en marxist, der med sine røntgenøjne kunne oplyse den politiske vej gennem historiens mørke for den diktaturhungrende tyske storkapital. Gådegætteriet antog næsten paniske dimensioner i partiledelsen.

Men som propagandamateriale for den kommunistiske valgkampagne, der netop var begyndt, kunne intet være kommet belejligere end denne anonyme artikel. I alle partiets aviser - og dengang var der flere - blev lange uddrag af den aftrykt og kommenteret sætning for sætning. Til sidst helligede Willy Münzenberg, lederen af partiets propagandaafdeling, umiddelbart før valget det sidste nummer af Roter Aufbau til artiklens uforkortede tekst som en sidste indskærpning:

»'Deutsche Führerbriefe', en privatkorrespondance for finanskapitalen, finansielt støttet af Reichsverband der Deutschen Industrie, strengt hemmelig og kun beregnet for den storkapitalistiske læsers orientering, udtaler åbent, hvad de offentlige aviser og tidsskrifter aldrig kunne sige. I numrene 72 og 73 af disse »Deutsche Führerbriefe« tales der med sjælden åbenhjertighed om, hvorledes finanskapitalen søger nye støtter til rekonsolideringen af sit herredømme. SPD's og NSDAP's rolle som det finanskapitalistiske herredømmes støtter beskrives, i borgerlig udtryksform, men alligevel klart, bourgoisiets nuværende hovedproblem - kapitalismen rekonsolidering - bliver så klart ridset op, at det ikke kan gøres bedre ... Alternativet er klart: Rekonsolidering af det finanskapitalistiske herredømme ved hjælp af SPD eller NSDAP eller kommunistisk revolution, således bliver det formuleret. Læseren kan heraf let gøre sig sine tanker «.

Navnet Deutsche Führerbriefe leder naturligvis tanken hen på Hitler. Med urette. Privatkorrespondancen blev grundlagt i slutningen af 1928 af Dr. Franz Reuter og Dr. Otto Meunen i Köln, altså på et tidspunkt da næsten ingen - ingen længere og endnu ingen - ved ordet »Führer« tænkte på Hitler. Alligevel var navnevalget inspireret, for grundlæggelsen af korrespondancen må regnes med til begyndelsessymptomerne på den kommende udvikling.

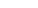

Ubrødelig bevaret anonymitet var naturligvis en grundsætning for et sådant foretagende, en omstændighed uden hvilken den her omtalte artikel ville have været umulig. Det er rigtigt, hvad Willy Münzenberg siger, at abonnenterne tilhørte de førende kredse inden for finans- og industrikapitalen med samt deres politiske tillidsmænd: kabinetsmedlemmer, spidser inden for Reichswehr, førende godsejere, Hindenburgs omgivelser etc. Führerbriefe var altså intet offentligt organ, og journalister var forment adgang.

\section{Ekskurs: Modsatningen mellem markedsøkonomi og arbejdsøkøkonomi i monopolkapitalismen.}

Den moderne produktionsvirksomhed er i løbet af sin industrielle udvikling blevet ude af stand til strukturelt at tilpasse sig markedsbevægelserne. Markedsøkonomien behersker ikke 
længere den samfundsmæssige reproduktion. Når efterspørgslen falder, og priserne synker, skulle produktionen kunne indskrænkes, og stykomkostningerne kunne formindskes. Men når en moderne storvirksomhed indskrænker produktionen og arbejder under sin kapacitet, går stykomkostningerne tværtimod i vejret, fordi en tiltagende del af omkostningsfaktoren er blevet uelastisk, selv når man ser bort fra de stadigt voksende faste omkostninger. I modsat fald, hvis en given produktionskapacitet når til fuld eller endog overbeskæftigelse, så formindskes stykomkostningerne og konkurrenceevnen vokser uden væsentlige merinvesteringer, således at profitterne svulmer mer overproportionalt op og fremkalder et boom, der ikke står i noget forhold til markedsudviklingen. I sin samlede effekt har produktionsstrukturernes egen økonomiske lovmæssighed altså i stadig højere grad tilintetgjort markedsøkonomiens regulative virksomhed. Men når produktionen ikke længere er i stand til at efterkomme markedets krav, så må man nødvendigvis forsøge at underkaste markedet produktionens krav. De tider er forlængst forbi, hvor en storvirksomhed blev lukket, fordi den efter markedets regulativer var bankerot; i dag manipulerer man i stedet markedsregulativerne. Metoderne til brug for denne manipulation er mangfoldige, men de falder alle mere eller mindre ind under samme overbegreb, monopolets. Monopolkapitalismen kan for en væsentlig del, og for den politisk betydelige del, forstås som et udslag af den antydede økonomiske tvekamp, en tvekamp, hvis begyndelse går tilbage til sidste fjerdedel af forrige århundrede. Det var især de kapitalstærke værker inden for sværindustrien, der var kendetegnet ved en høj organisk sammensætning af kapitalen, som var førende i denne udvikling. Det gælder ikke bare de amerikanske, der blev Taylorismens vugge, men ikke mindre de europæiske, specielt de tyske. Det lønner sig at illustrere modsætningerne i denne tvekamp mellem virksomhedsog markedsøkonomi ved et særligt betydeligt eksempel, nemlig Stahlverein eller Luxemburger ARBED i tyverne og trediverne.

Die Vereinigten Stahlwerke AG (Vestag) blev grundlagt i 1926 ved en sammensmeltning af fire eller fem selvstændige sværindustrielle koncerner, der indtil da havde konkurreret (eller i det mindste været rettet mod de samme mål). Af disse værker blev der ved "rationalisering" dannet et arbejdsdelt hele. Den samlede kapacitet udgjorde ca. $40 \%$ af den tyske produktion af råstål og $50 \%$ af den tyske produktion af råjern (i absolutte tal 9,3 mill. t. råstål og 9,7 mill. t. råjern om året). Med 200.000 arbejdere og funktionærer ved fuld beskæftigelse var de det største industriforetagende i det daværende Europa. Men skønt de ikke er ligegyldige, interesserer de, absolutte dimensioner os mindre end de strukturelle aspekter. Rationaliseringen var foretaget på grundlag af den såkaldte fælles driftsøkonomi, hvorved højovnsgassen, som man tidligere havde ladet forsvinde i luften, efter amerikanske forbilleder blev opfanget i store rørledninger og som varme- og energikilde ledt ind i alle afdelinger af værket. Ingen enkelt produktionsafdeling havde længere sin egen energikilde, ingen kunne drives udenfor den fælles drift. De samlede anlæg lignede en eneste mekanisme, der fra et uhyre, centralt anlagt kontrolværk kunne overvåges og reguleres af en overingeniør og to assistenter ved hjælp af komplicerede symboler og lyssignaler og holdes i sin forudberegnede og kontinuerlige bane. Til grund for det hele lå normeringen af en bestemt samlet kapacitet, ved hvis udnyttelse produktenhederne (hundreder af kartelnumre på halvfabrikata, valseværks-, tråd- og rørprodukter) kunne fremstilles billigere end nogensinde før, ganske vist kun hvis normalkapaciteten blev udnyttet. Hvad skete der, hvis det ikke var tilfældet? Allerede i 1928 og 1929, altså under højkonjunkturen, udgjorde Stahlvereins markedskapacitet næppe mere end $75 \%$ af produktionskapaciteten. Der var derfor kun to muligheder: enten at producere for lageret og derved altså gøre markedssituationen endnu værre eller at nedsætte produktionstempoet. Men en nedsættelse af tempoet kunne ikke komme under en grænse på 68-70\% af normakapaciteten, uden at mekanismen rent teknisk vægrede sig ved at fungere. (Sådanne øvre som nedre »kritiske grænser « findes altid). Og så kom krisen. I 1931 drejede det sig ikke længere om $75 \%$, men om kun knap 40\%, i bølgedalen 1932 om en ordrebestand på mindre end 20\%, og den var naturligvis ikke regelmæssigt fordelt på alle dele af produktionsprogrammet, men på nogle var der noget, på andre noget mer, på mange intet. Allerede i påsken 1932 blev ARBED’s anlæg, og, så vidt jeg ved, også Vestag's skiftevis standset i fjorten dage og sat i gang i fjorten dage, hvad der var forbundet med besværlige og kostbare start- og friktionstab. De faste omkostninger løb naturligvis også videre i perioder med stilstand, ligesom betydelige lønomkostninger til vedligeholdelse etc. Det kræver ingen udførlig bevisførelse for at indse, at anlæg af denne art, langt fra 
at tilføre driftskapitalen profit eller endog kun tab, begyndte at fortære deres egenkapital, stadig forudsat, at egenkapitalen var deres egen og ikke, som i Stahlverein's tilfælde, skyldtes dollarkreditorer. Et foretagende i denne situation er ude af stand til at vente på, at markedssituationen muligvis forbedres.

Professor Ernst Schmalenbach, den betydelige lærer i driftsøkonomi i Köln, der deltog i rationaliseringen af Stahlverein som rådgiver, forfattede i efteråret 1931 en betænkning, hvori han gav logikken æren og erklærede, at sådanne planlagte kæmpeværker som Stahlverein forudsatte en planlagt nationaløkonomi for at være til gavn for samfundet. Dette memorandum fremkaldte en sådan indignation hos de industridrivende, især hos dem, som det drejede sig om, at økonomiminister Dietrich straks undertrykte det og lod det beslaglægge. Efter en markedsøkonomisk målestok var disse firmaer i hvert fald siden 1931 bankerot - og med dem mange andre - men med den eksisterende massearbejdsløshed var det politisk umuligt at lukke dem. Hvad denne fuldstændige splittelse mellem driftsøkonomi og markedsøkonomi indicerede, var den kapitalistiske produktionsforms bankerot som sådan. Men da den sociale revoluion udeblev, var der intet andet alternativ end at videreføre den kapitalistiske produktion uafhængigt af markedet, d.v.s. med fremstilling af produkter, der ikke var beregnet på salg af ren driftsøkonomisk nødvendighed. Det er den økonomiske definition på fascismen; den tyske fascisme var i praksis et produkt af et borgerskab, der var fortvivlet over ikke længere at kunne kontrollere sin økonomi.

Helt i den modsatte lejr, i opposition til Stahlverein, var IG Farben, vel den stærkeste af alle de daværende tyske koncerner og som ingen anden betænkt på sin uafhængighed. Hvad fik denne finansielle stormagt til at opgive sin splendid isolation og tilslutte sig gruppen omkring Hitler, ganske vist først i elvte time, i begyndelsen af december 1932?

Da IG Farben i 1930 og 1931 gik i gang med at virkeliggøre de fabrikationsplaner, der var projekteret i deres berømte kartelaftale med Standard Oil of New Jersey i 1929, gjorde man i Leunaværket, der var bygget til benzinpolymerisering efter Bergiusmetoden, den slående erfaring, at de processer, der var fuldstændigt bekræftigede i laboratoriet og endog gennemprøvet i et modelanlæg, gav et kvalitativt andet og ubrugeligt resultat - tilsyneladende kun for- di de skulle virkeliggøres i forstørret skala. Her var så at sige kvantiteten slået over i kvalitet, og resultatet var, at benzinsyntesen spottede alle privatkapitalistiske omkostnings- og profitkalkulationer og udsatte selv det daværende Tysklands mest kapitalstærke foretagende for faren for bankerot. Disse erfaringer har dengang bidraget ikke så lidt til at drive IG Farben over i Hitlers lejr, nemlig i den statslige form for monopolkapitalisme, der i dag har vundet indpas i alle førende imperialistiske lande, og hvormed Hitlers rustningskapitalisme ved omstillingen til produktion af ikke-reproduktive værdier hjalp med til at overvinde privatkapitalismens endelig krise i trediverne.

Varer, der ikke fremstilles for markedet, er ikke-reproduktive værdier, fremstillingen af dem tjener ødelæggelsen i stedet for reproduktionen af det samfundsmæssige liv. Hitler og Schacht har praktiseret keynesianismen to år før fremkomsten af denne vildledende civilteori. I den »militært-industrielle« virkelighed er den siden da blevet endemisk i alle sen- og overkapitalistiske lande. "Hvis revolutionen kommer for sent, begynder hele lortet forfra igen, «siger Marx et eller andet sted og mener dermed den menneskelige histories lort.

Så kommer vi endnu engang tilbage til det spørgsmål, der dengang og siden har vakt så stor forundring: Hvordan kom en artikel med et så entydigt marxistisk indhold i dette kritiske øjeblik ind i Deutsche Führerbriefe? En artikel, hvis skæbne på dette tidspunkt ikke kunne blive nogen anden end at blive brugt af Det kommunistiske Parti som hovedpropagandamateriale fra slutningen af september til 6 . november? Gådens løsning er så enkel, som man kan tænke sig: Artiklen var forfattet alene til brug for kommunisterne i denne valgkamp. Ikke sådan, at Det kommunistiske Parti havde bestilt den. Partiet vidste hverken noget om artiklens affatning eller om dens forfatter. Jeg skrev den på eget initiativ og sendte et eksemplar til Rote Fahne, efter at den var fremkommet i Führerbriefe. Mere krævedes der ikke, for at bomben var antændt. Af didaktiske grunde antog jeg i artiklen storkapitalens synsvinkel for at gøre arbejderne klart, at såvel Socialdemokraterne som nazisterne kun tjente som støttem for kapitalens herredømme, som "grænsebærere«. Naturligvis havde arbejderne og masserne af antikapitalistiske vælgere allerede hørt det mange gange før, men endnu 
aldrig fra storkapitalens talerør selv og med udseendet af uomstødelig beviskraft. Hvis man overhovedet ville drive virksom marxistisk propaganda, som viste arbejderne den truende fare for spaltning, så kunne det bedst ske ad denne omvej. Og ad den samme omvej kunne man indprente Det kommunistiske Parti, hvor nødvendigt det var at sætte den proletariske revolution på dagsordenen som det eneste mulige praktiske alternativ til det fascistiske diktatur. Med denne indsigt stod det meget dårligt til hos partiets ledelse. Deres tankegang syntes ikke at række ud over en enhedsfront med socialdemokraterne til redning af »demokratiet«, hvor det i virkeligheden kun var revolutionen, med efterfølgende industrielt planfællesskab med Sovjetunionen, der i det mindste teoretisk havde kunnet være et alternativ til fascismen. Den store, politiske trafikarbejderstrejke i Berlin i begyndelsen af november syntes at bekræfte mit initiativ i begge henseender, for advarslen mod spaltningsfaren og for revolutionens mulighed, meget mere eftertrykkeligt end valgene gjorde det, hvor en stemmefremgang på en million for kommunisterne ikke kunne udrette meget, når det tyske proletariat stadig var spaltet.
Der er endnu en anden del af spørgsmålet tilbage at besvare, nemlig hvordan det kunne lykkes at benytte den på ingen måde politisk ubegavede redaktion af Führerbriefe til en så ekstremt modsigende funktion. Jeg kan kun sige, at det virkeligt også ville være ubegribeligt, hvis ikke kapitalens snu ræve netop var temmelig ubegavede, hvor det drejer sig om erkendelse og ikke blot manipulation.

Den storkapitalistiske magts kerne ser alligevel anderledes ud end mange plankeværkskiggere forestiller sig den. I denne kerne hersker på trods af al snuhed fuldstændig forvirring, og intet kan være den mere fremmed end dens eget begreb.

Oversat af Jan Bo Hansen.

1. (Die soziale Rekonsolidierung des Kapitalismus, Deutsche Führerbriefe, september 1932. Genoptrykt i Kursbuch $21,1970)$

2. (I oversættelsen fra Sohn-Rethel's kommentar er der udeladt nogle passager, der indeholder en beskrivelse af den tyske industris stilling i mellemkrigstiden. Interesserede henvises til Kursbuch 21).

3. (fra Geistige und körperliche Arbeit, Frankfurt 1970, s. 140-144) 